\title{
DE KUNST VAN HET VERZAMELEN \\ KOLONIALE VERZAMELAARS EN DE VVAK
}

Wat heden ten dage als kunst uit Indonesië wordt beschouwd, werd niet altijd als kunst gezien. Wat bovendien tegenwoordig in Nederland onder Indonesische kunst wordt verstaan, is aanzienlijk beinvloed door de praktijk van verzamelen zoals dat gedurende de $19^{\circ}$ eeuw plaatsvond in de kolonie Nederlands-Indië. De collectie van de Vereniging van Vrienden der Aziatische Kunst (VVAK) behelst natuurlijk meer dan alleen voorwerpen uit de voormalige Nederlandse kolonie. Toch was, zoals hier te lezen valt, de kolonie Nederlands-Indië van invloed op de vorming van de vereniging in 1918 en het begin van de collectie.

De opmerking van kunsthistorica Renée Steenbergen in Aziatische Kunst (2008) dat er, ondanks de betrekkingen die Nederland onderhield met Nederlands-Indië en (tot 1854) met Japan, maar weinig Aziatische kunst werd verzameld, ${ }^{1}$ suggereert dat de invloed van de kolonie op de VVAK minimaal was. Ik zal in dit artikel betogen dat er op de stichting en ontwikkeling van de vereniging en de perceptie van wat Indonesische kunst is wel degelijk een aanzienlijke invloed was van verzamelaars uit Nederlands-Indië.

\section{Het begin: Engelhard en Raffles op vroeg $19^{\mathrm{e}}$-eeuws Java}

Er werd al sinds het eind van de $18^{\mathrm{c}}$ eeuw op Java verzameld door particulieren. Dit was een elitaire bezigheid: het lidmaatschap van het in 1778 opgerichte Bataviaasch Genootschap van Kunsten en Wetenschappen, dat zich interesseerde in de culturen van de kolonie, vereiste namelijk dat men vermogend en aanzienlijk moest zijn. Daarnaast vereiste verzamelen over het algemeen enig financieel kapitaal. De redenen om in de $19^{c}$ eeuw te gaan verzamelen en zich vervolgens eventueel te verbinden aan het Bataviaasch Genootschap waren over het algemeen heel divers. ${ }^{2}$ Aan het begin van de $19^{\mathrm{e}}$ eeuw werd er op kleine schaal vooral Indo-Javaanse voorwerpen uit Oost- en Centraal-Java verzameld. De reden van dit specifieke verzamelen op bescheiden schaal moet men vooral praktisch zien: niet alleen was de Europese gemeenschap klein en de belangstelling minimaal, maar ook was de directe politieke macht gecentreerd op Java in de ruime omgeving van Batavia, de Javaanse noordoostkust, Centraal- en Oost-Java. De antieke voorwerpen waar de Europeanen dan ook het eerst mee werden geconfronteerd waren de overblijfselen van de grote Javaanse koninkrijken die van de $10^{c}$ tot de $16^{\mathrm{c}}$ eeuw in Oost- en Centraal-Java hun regeringscentra hadden gehad.

De vroegste verzamelaars van dit soort voorwerpen waren Nicolaus Engelhard (1761-1831), de tussen 1801 en 1808 in Semarang geplaatste gouverneur van het bestuursgebied Java's Noordoostkust, en Thomas S. Raffles (1781-1826), de Britse gouverneur-generaal van Java tussen 1811 en 1815. Raffles zou voortbouwen op Engelhards bevindingen in zijn poging Java etnografisch $h_{e}: 39: 48 \mathrm{Am}$ 
historisch te doorgronden. Engelhard had tussen 1805 en 1806 door majoor H.C. Cornelius en tekenaar vaandrig-ingenieur Johannes W.B. Wardenaar de tempelruïnes van Centraal-Java in kaart laten brengen en enkele beelden daar vandaan naar zijn huis in Semarang laten brengen. Net als Engelhard bezat Raffles stenen beelden uit de Oost-Javaanse boeddhistische tempel Candi Jago en een stenen hoofd afkomstig van de rond de $9^{e}$ eeuw gebouwde boeddhistische tempel Borobudur. Vooral hoofden van Boeddhabeelden die gesitueerd waren in de hoogste omgangen van de rond 1814 herontdekte Borobudur waren geliefde verzamelobjecten: in Indië verbleven verscheidene in particuliere collecties, werden verschillende hoofden in de Borobudur omringende dorpen bewaard en op het kerkhof van Magelang sierde een hoofd het graf van een christelijke Ambonees. ${ }^{3}$ In 1818 arriveerde het eerste hoofd (dat door onbekendheid met de Javaanse kunst en cultuur per ongeluk voor een vrouwenhoofd werd aangezien) in Nederland. ${ }^{4}$

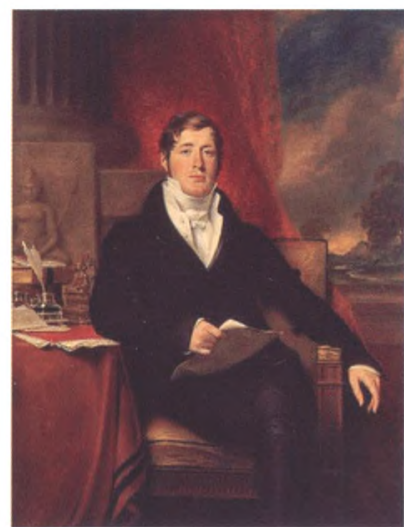

Afbeelding 1

Thomas S. Raffles, (1781-1826), de Britse gouverneur-generaal van Java tussen 1811 en 1815 , met zijn geliefde Indo-Javaanse beelden (zie ook afb. 2), geschilderd door George Francis Joseph. Portret, olieverf op doek, hoogte $130 \mathrm{~cm}$., breedte $100 \mathrm{~cm} ., 1817$, National Portrait Gallery Londen, inv.nr. NPG84.
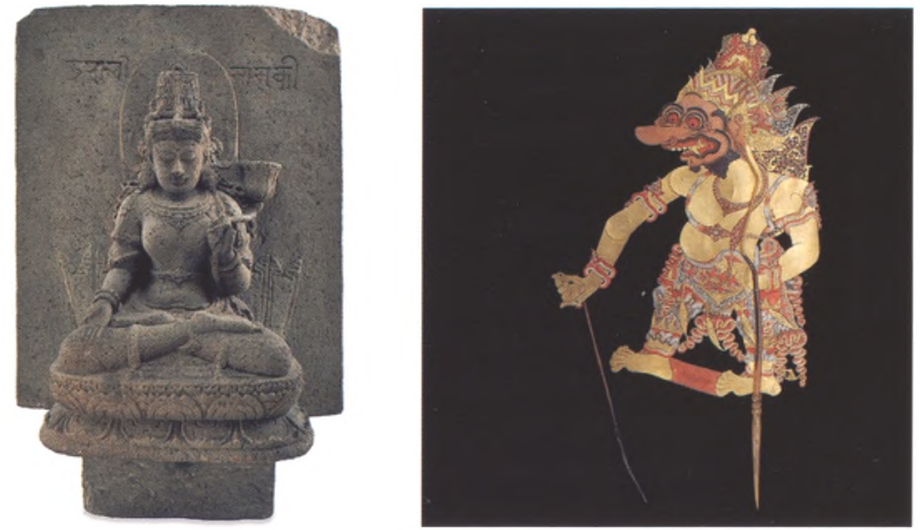

Afbeelding 2

De stenen figuur van de godin Mamaki werd door Raffles in 1815 uit Candi Jago, Oost-Java, meegenomen. Raffles hield zo van dit beeld dat hij zich door C.F. Joseph in 1817 liet portretteren met dit beeld op de achtergrond. Dit portret bevindt zich nu in de National Portrait Gallery in Londen. Mamaki, steen, hoogte $48 \mathrm{~cm}$., Candi Jago, Oost-Java, $13^{e}-14^{e}$ eeuw, British Museum, inv.nr. Asia OA 1859.12-28.171
Afbeelding 3

Raffles was een van de eersten die etnografica ging verzamelen. Deze pop is daardoor vermoedelijk een van de vroegst bekende wayang-kulit poppen in Europese collecties.

Wayang kulit-pop: de reus Kumbakarna, hoogte $66 \mathrm{~cm}$., Java, begin $19^{e}$ eeuw, British Museum, inv.nr. Ethno 1859, 12-28.547.

Raffles was een van de eersten die ook etnografische objecten zou gaan verzamelen. De collectie die hij aldus tot stand bracht, zou de blauwdruk worden voor de inhoud van veel etnografische koloniale collecties. Hij verzamelde vooral batiks, ikats, wapens, topeng-maskers, wayang-poppen, volkenkundige poppen en een gamelan. Toch bleven voor Raffles 'zijn' IndoJavaanse beelden het meest bijzonder: hij liet zich dan ook portretteren omringd door zijn geliefde beelden uit Singosari (afb. 1 en 2). 
niet met kalk, verf of zelfs koolteer bewerkte beelden waarvan sommige nog geheel intact, maar andere half vergaan waren. Rijke Chinese zakenlui en fabriekseigenaars en Indonesische (Javaanse) regenten namen het gebruik van de Europese elite over. Men vond dat deze oude beelden het cachet van een huis of stad opvijzelden: zo werd ter opluistering van het bezoek van de gouverneur-generaal in Kediri de stad versierd met inderhaast uit de binnenlanden aangevoerde antieke beelden, ${ }^{5}$ doneerde een rijke Chinees zijn beelden aan de stadstuin van Pasuruan ${ }^{6}$ en werd een oude pasangrahan ten behoeve van de ontvangst van de gouverneur-generaal rijkelijk versierd met beelden die waren weggesleept van hun oorspronkelijke plaats bij de Prambanan-tempels. ${ }^{7}$ Het lijkt vooral te gaan om de ouderdom van de beelden - waar ze vandaan kwamen (de meeste beelden waren tenslotte van hun oorspronkelijke standplaats verwijderd) was minder van belang. Er was in de loop van de $19^{\mathrm{c}}$ eeuw een levendige handel in die beelden op gang gekomen: de beelden werden, als ze niet in het bezit kwamen van lokale liefhebbers, vanuit Centraal- en Oost-Java via de noordoostkust van Java afgevoerd naar Batavia of Nederland (in ieder geval tot 1840 , toen het verboden werd dat zonder toestemming van de autoriteiten te doen). Aan die kust konden dan ook heuse 'stapelplaatsen' van Indo-Javaanse antieke beelden ontstaan.

\section{De Java-oorlog, 1825-1830}

De traditie van het verzamelen van Indo-Javaanse beelden en vooral kleinere voorwerpen werd nog verder gestimuleerd door de Java-oorlog van 1825 tot 1830. Deze oorlog was uitgebroken door onvrede die onder de Javaanse aristocratie was ontstaan vanwege door het gouvernement afgekondigde maatregelen om misstanden in de verpachting van grond tegen te gaan, aanhoudende droogte en het uitbreken van een cholera-epidemie. Prins Diponegoro (1785-1855) uit het hof van Yogyakarta had de algemeen verbreide onvrede gekanaliseerd. Het zou leiden tot een langdurige, heftige oorlog van Javanen tegen Europeanen en Chinezen. Tijdens de in CentraalJava uitgevoerde militaire campagnes stuitten de Europese militairen op de ontredderde en door voedselschaarste en cholera verzwakte bevolking. Het is goed mogelijk dat op dat moment de bevolking, om een beetje geld te verdienen, haar pusaka, heilige erfstukken, is gaan verkopen. Veel Indo-Javaanse voorwerpen waren, nadat $z \mathrm{ij}$ sinds de $18^{\mathrm{e}}$ eeuw hun oorspronkelijke betekenis hadden verloren, namelijk pusaka geworden in vooraanstaande adellijke Javaanse families. ${ }^{8}$ Men verkocht pusaka liever niet, maar tijdens de Java-oorlog werd de nood hoog: men moest overleven. Er zijn verschillende collecties, zoals de collectie van Frans G. Valck (1799-1842), de resident van Kedu, die als onderhandelaar bij de militaire eenheden was gevoegd, die vermoedelijk direct te herleiden zijn tot deze oorlog. Valck en andere Europeanen waren geïntrigeerd door deze oudheidkundige objecten waarvan men niet kon geloven dat zij van de hand van de voorouders van de Javanen waren: men veroordeelde de Javaan wetenschappelijk en cultureel als achterlijk en onwetend. De prachtige objecten en monumenten moesten wel door een volk uit India zijn vervaardigd. Valck was baanbrekend met zijn opvatting dat de Javaan het waarschijnlijk onder leiding van de Indiër zal hebben vervaardigd. ${ }^{9}$ Met deze opvattingen eigenden de Europeanen zichzelf de kunst toe als onderdeel van de universele Westerse geschiedenis: er werden verbanden gezien tussen de Indo-Javaanse objecten en voonwerpen access 
uit India en de Griekse klassieke wereld. ${ }^{10}$ Op deze wijze werden die vreemde Aziatische cultuur en geschiedenis in de eigen geschiedenis ingebed, en werd het legitiem die objecten te verzamelen. Bovendien kon de Europeaan zich nu als eigenlijke erfgenaam en beschermer van de lokale geschiedenis opwerpen. Wat deze laatste gedachte versterkte, was de onder de Europeanen levende overtuiging dat de Islam de boeddhistisch-hindoeïstische cultuur op Java had vernietigd en dat de overblijfselen daarvan behoed moesten worden voor nog meer vernielzucht. De Indo-Javaanse cultuur kwam te staan voor beschaving en hoge cultuur, terwijl de Islamitische, levende cultuur werd afgedaan als minderwaardig en niet het verzamelen waard. Het verzamelen van voorwerpen uit die levende culturen ('etnografica') vond pas plaats aan het eind van de $19^{\mathrm{e}}$ eeuw.

De Java-oorlog leidde tevens tot het verzamelen van 'souvenirs'. De $19^{\mathrm{e}}$ eeuw was de eeuw van de opkomst van het historisch bewustzijn: uit vrees dat belangrijke gebeurtenissen zouden worden vergeten, begon men voorwerpen te verzamelen die de herinnering aan die gebeurtenis konden oproepen: dit waren 'souvenirs'. In de Java-oorlog waren deze souvenirs tegelijkertijd ook trofeeën, zegetekens van de oorlog. Een groot aantal officieren uit de Javaoorlog bezaten zelfs de pusaka, de heilige erfstukken, van hun tegenstanders. De oorlog kon niet symbolischer worden opgeëist dan door beslag te leggen op die voorwerpen die het belangrijkste bezit van een Javaan waren: zijn pusaka, de voorwerpen die macht legitimeerden en identiteit bepaalden. De pusaka die het neerslaan van de Javaanse opstand en het onder gezag brengen van de Javaanse aristocratie het best verbeeldden waren krissen: krissen waren tenslotte niet alleen pusaka, maar ook oorlogswapens. Zo zijn er maar liefst vijf diverse krissen van Diponegoro mij bekend. Alle vijf werden door hun eigenaren gepresenteerd als dè kris van Diponegoro, als symbool voor de almacht van het Nederlandse gezag en de onderwerping van de Javaan. Ook andere pusaka van Diponegoro werden verzameld: een godenbeeld en een lans. En de met diamant bezette krissen en pieken van Sentot, de rechterhand van Diponegoro, waren evenzo in handen van Nederlandse officieren gekomen. Het verhaal over dè kris van Diponegoro is merkwaardig omdat diverse officiële bronnen vermelden dat de Nederlanders de krissen aan Diponegoro en zijn medestanders hadden teruggegeven. Uiteraard is het mogelijk dat niet iedere soldaat hieraan gehoor gaf. Bovendien was het op het moment van Diponegoro's arrestatie, aldus Pim Westerkamp, conservator Cultuur en Geschiedenis van Zuidoost-Azië in het Tropenmuseum, Islamitische vastentijd en dus niet gebruikelijk om wapens te dragen, en het feit dat er toch talloze krissen in omloop zijn, geeft dan ook aanleiding tot een andere theorie. Het verzamelen van de zogenaamde pusaka van Diponegoro was waarschijnlijk eerder een Nederlandse constructie van politiek machtsvertoon dan werkelijkheid.

Gepresenteerd aan publiek herinnerden deze souvenir-trofeeën Europeanen in de kolonie en in Nederland aan de overwinningen van het Nederlandse gezag in de Oost en de persoonlijke rol die de verzamelaars van de voorwerpen daarin hadden gespeeld. De buitgemaakte objecten werden nationale symbolen, zeker rond 1850 toen het Nederlands nationalisme steeds meer aan het bezit van de kolonie werd gekoppeld. Tegelijkertijd maakten de objecten onbedoeld ook duidelijk hoe instabiel de politieke macht van de Nederlanders in hun kolonie was en hoe latent de dreiging van onrust was in de uitgestrekte archipel. Downloaded from Brill.come4/26/2023 81:39:48AM 
Deze sterk toegenomen bezigheid van verzamelen en de belangstelling voor de antieke overblijfselen op Java leidden ertoe dat de nieuwe directeur van het Bataviaasch Genootschap, Wolter R. baron van Hoëvell (1812-1879), zich inzette voor de verwerving en het behoud van deze voorwerpen.

Het werkelijke begin van de archeologische collectie van het museum van het genootschap is dan ook het moment waarop Van Hoëvell besloot de collectie antieke godenbeelden van de in 1842 overleden Frans Valck voor het museum aan te kopen. Dit was het begin van de oudheidkundige collectie in het museum van het genootschap in Batavia, het huidige Museum Nasional Indonesia.

Veel van deze in de eerste decennia van de $19^{\mathrm{e}}$ eeuw verzamelde voorwerpen werden niet onmiddellijk opgenomen in museumcollecties. Veelal bezaten zij voor hun eigenaars en families een duidelijke sociale functie als identiteitsvormende en daarmee statusverhogende souvenirs. Daarnaast konden ze dienen als smeermiddel in sociale relaties. De verzamelde voorwerpen werden dan ook door de Europese elite verkocht, overerfd en geschonken aan vrienden en familie. De beroemde collectie Indo-Javaanse beelden en voorwerpen (voor het merendeel eigenhandig opgegraven middenin de tempels van Prambanan en Borobudur) en 'wonderlijke natuurvoortbrengsels' van Jacob A. Dieduksman (1832-1901) in Yogyakarta werd na zijn dood voor een groot deel aangekocht door mede-verzamelaars zoals mevrouw Anna J. Resink-Wilkens (1880-1945), door verzamelaars in Nederland met een Indische achtergrond en Europese musea. ${ }^{11}$ De resident van Yogyakarta kreeg geregeld van planters antieke voorwerpen die door henzelf of lokale boeren tijdens hun werk in de omgeving gevonden waren: de eerder genoemde resident Frans Valck was niet de eerste en de laatste resident die voorwerpen ontving van landhuurders uit de omgeving. ${ }^{12}$ Vaandrig-ingenieur Wardenaar, die samen met majoor Cornelius ook voor Raffles in 1815 de oude tempels van Oost-Java had geïnspecteerd, had in de bodem van een heiligdom op de helling van de Pananggungan een stenen kist gevonden met daarin enkele gouden voorwerpen als beschreven plaatjes, dierfiguren en een prachtig doosje. Wardenaar, geboren in Indië uit een vermoedelijk

Euraziatische moeder en een in Leiden geboren lid van de Raad van Indië en zelf getrouwd met een Javaanse, was doordrongen van de historische waarde van het voorwerp en bewaarde de stenen kist met de voorwerpen voor zichzelf. Na zijn dood in 1869 viel zijn collectie uiteen: het museum van het Bataviaasch Genootschap verwierf de stenen kist waarin Wardenaar de voorwerpen had gevonden en de toentertijd beroemde verzamelaar $\mathrm{G}$. Scheepmaker verwierf de gouden voorwerpen die in de kist hadden gezeten. Scheepmaker raakte in de jaren 1870 echter in financieel zwaar weer en begon zijn collectie te verkopen: de in 1875 benoemde gouverneurgeneraal J.W. van Lansberge (1830-1903) gunde hij behalve 12 koperen platen met inscripties ook de gouden dierfiguurtjes, beschreven gouden plaatjes en het kostbare doosje van Wardenaar. Van Lansberge schonk het geheel vervolgens kort daarna aan het museum van het Bataviaasch Genootschap toen hij erachter kwam dat de stenen kist waarin Wardenaar de voorwerpen had gevonden in het museum stond. Deze voorbeelden van het schenken en gunnen van voorwerpen van verzamelaars aan geïnteresseerde hoge ambtenaren moeten ongetwijfeld als relatiegeschenken gezien worden: een manier om goodwill op te bouwen. Downloaded from Brill. come4/26/2023 01:39:48AM 


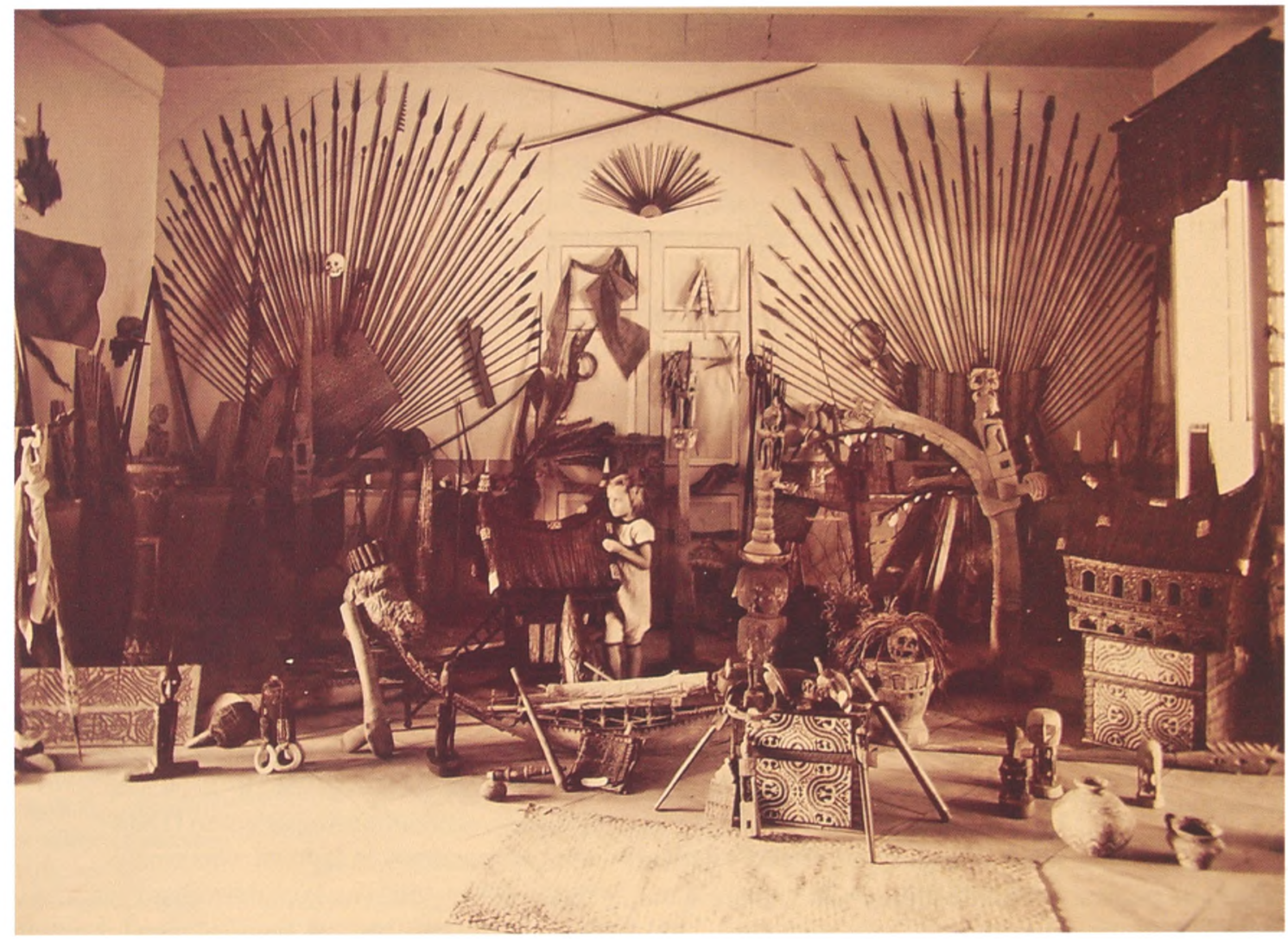

Afbeelding 4

Hendrik J.A. Raedt van Oldenbarnevelt (18601936) was van augustus 1910 tot 1915 resident van Ambon en een fervent verzamelaar van etnografica. Speciaal daarvoor richtte hij een, wat hij zelf noemde, 'rariteitenkamer' in en maakte daarvan een foto. Foto, Ambon, ca. 1910-1915, collectie Tropenmuseum, archief Koninklijk Instituut voor de Tropen, inv.nr. 4403.

\section{De opkomst van het verzamelen van etnografica rond 1900}

Aan het eind van de $19^{e}$ eeuw nam het verzamelen van etnografica een vlucht. Voor die tijd was etnografica vooral verzameld door lokale ambtenaren, die de voorwerpen ontvingen als diplomatieke geschenken, en door wetenschappers. Onder invloed van verschillende factoren veranderde dit. Rond het fin de siècle kwamen 'primitieve' en exotische kunsten in Europa zeer in trek: ze boden een uitvlucht voor de zich snel ontwikkelende, industriële en individualistische samenleving met zijn massaproductie, en beantwoordden aan de hang naar het eenvoudige, traditionele, en naar handwerk.

Tegelijkertijd ontstond in deze periode in zowel Europa als in haar koloniën de overtuiging dat de lagere klassen van het volk 'opgeheven' moesten worden: het volk moest meer welvaart krijgen, zich door onderwijs sociaal ontwikkelen en beschaving aanleren. Dit werd voor de koloniën met de afkondiging van de zogenaamde Ethische Politiek officieel beleid in 1901. Deze combinatie van factoren leidde ertoe dat er in Nederland een grotere belangstelling kwam voor de kunst(nijverheid) uit de Nederlandse kolonie: onder invloed van Europese culturele ontwikkelingen en de angst cultuur te verliezen, werd veel in het werk gesteld om de kunstnijverheid te behouden, te ontwikkelen en te bewaren voor het nageslacht. Tegelijkertijd wilde men, onder invloed van de Ethische gedachte, de oorspronkelijke bevolking 'verheffen' door hen te helpen hun kunst 'terug' te brengen en hen tegelijkertijd daarmee te laten verdienen door een afzetmarkt voor de voorwerpen te vinden. 
Afbeelding 6 (links) Kandelaar met drie armen van oud Javaanse oorsprong. De drie lampen vormen een lotusbloem. Kandelaber, brons, hoogte $38 \mathrm{~cm}$., Kretek, Centraal-Java, $8^{e}-9^{e}$ eeuw, Museum Sono Budoyo, Yogyakarta, Indonesië

Afbeelding 7

Familie Resink, foto, $10 \times 10 \mathrm{~cm}$., collectie Resink, C.J., ca. 1920, Koninklijk Instituut voor Taal-, Land-en Volkenkunde, Leiden, fotosignatuur 404270 . sterk afhankelijk van tussenpersonen, zogenaamde langganans, die de begeerde objecten voor de vrouwen opspoorden en bij ze aan huis brachten. Dit bepaalde natuurlijk het aanbod en de kwaliteit, maar maakte ook duidelijk hoezeer verzamelen scheidslijnen in de maatschappij trok: het verzamelen en determineren van de objecten deed de Europese elite, het opsporen van de voorwerpen deed de lokale bevolking. Want als nette, Europese vrouw kon je je niet zomaar in de kampong vertonen!

\section{De Vereniging van Vrienden der Aziatische Kunst in Nederland}

Als gevolg van de toename in populariteit van etnografica in Nederland en het bekender raken van de Indo-Javaanse kunst in Nederland door de toepassing van haar motieven door Art Nouveaukunstenaars als C.A. Lion Cachet (1864-1945), werd de belangstelling voor Aziatische kunst in het algemeen groter. Deze ontwikkelingen leidden tot de oprichting van de VVAK in 1918. Bestuurslid en conservator Herman F.E. Visser (1890-1965) bracht kort na de opening onder woorden wat de vereniging verstond onder Aziatische Kunst. In dit manifest ziet men voor het eerst een scherpe scheiding ontstaan tussen wat de vereniging 'waarachtige kunst' noemde en etnografica. 'Waarachtige kunst' was 'echte' kunst en was geïnspireerd door het rake 'doen' van een kunstenaar. Visser constateerde een groot maatschappelijk nut van een dergelijke collectie voor de natiestaat Nederland met zijn koloniën: de collectie zou bij velen die daarvoor esthetisch ontvankelijk waren de belangstelling opwekken voor de gekoloniseerde volkeren en koloniën. Met een dergelijk museum kon het publiek kennisnemen van de Nederlandse koloniën en zich laten doordringen van de grootsheid van het
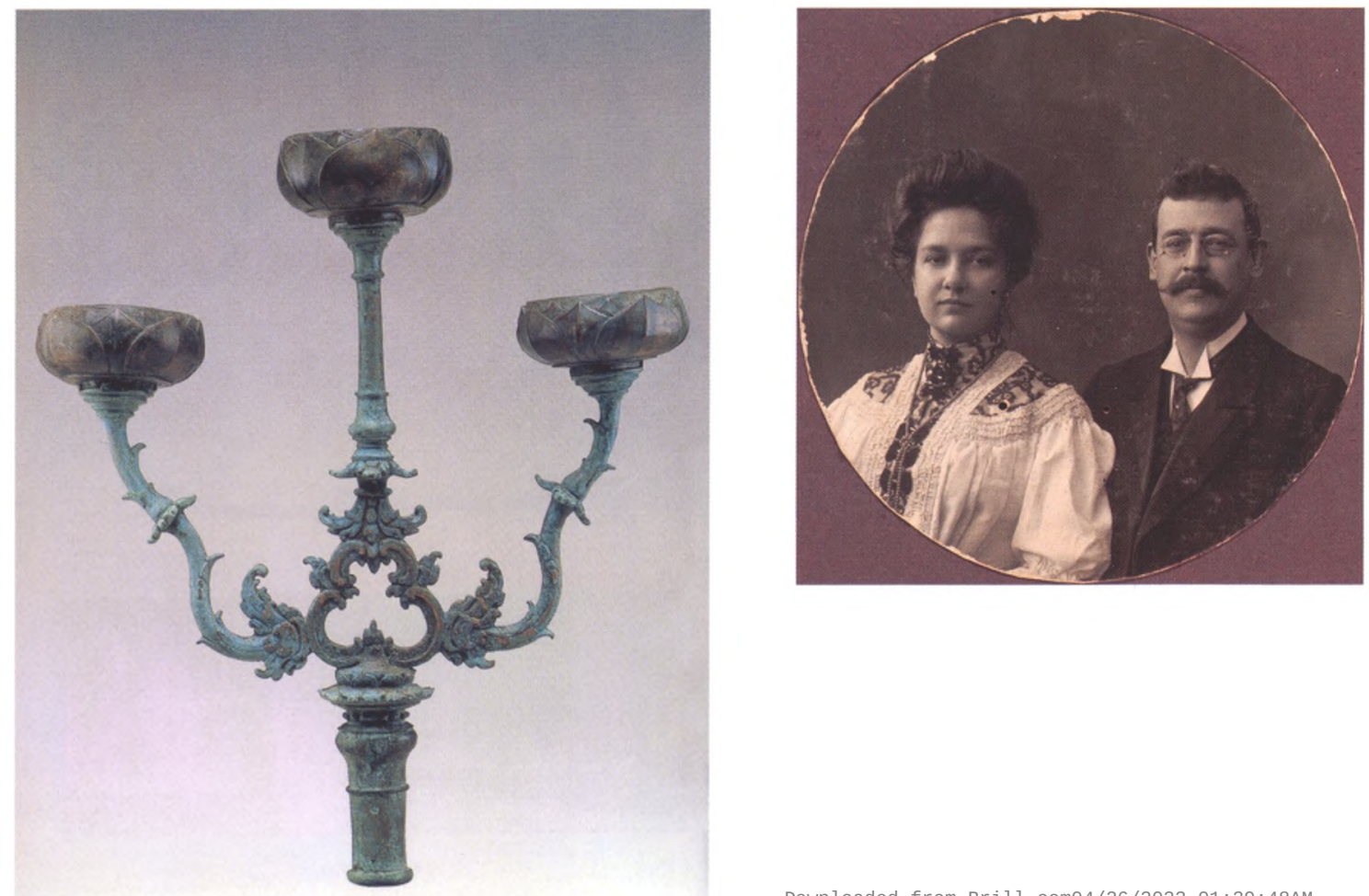


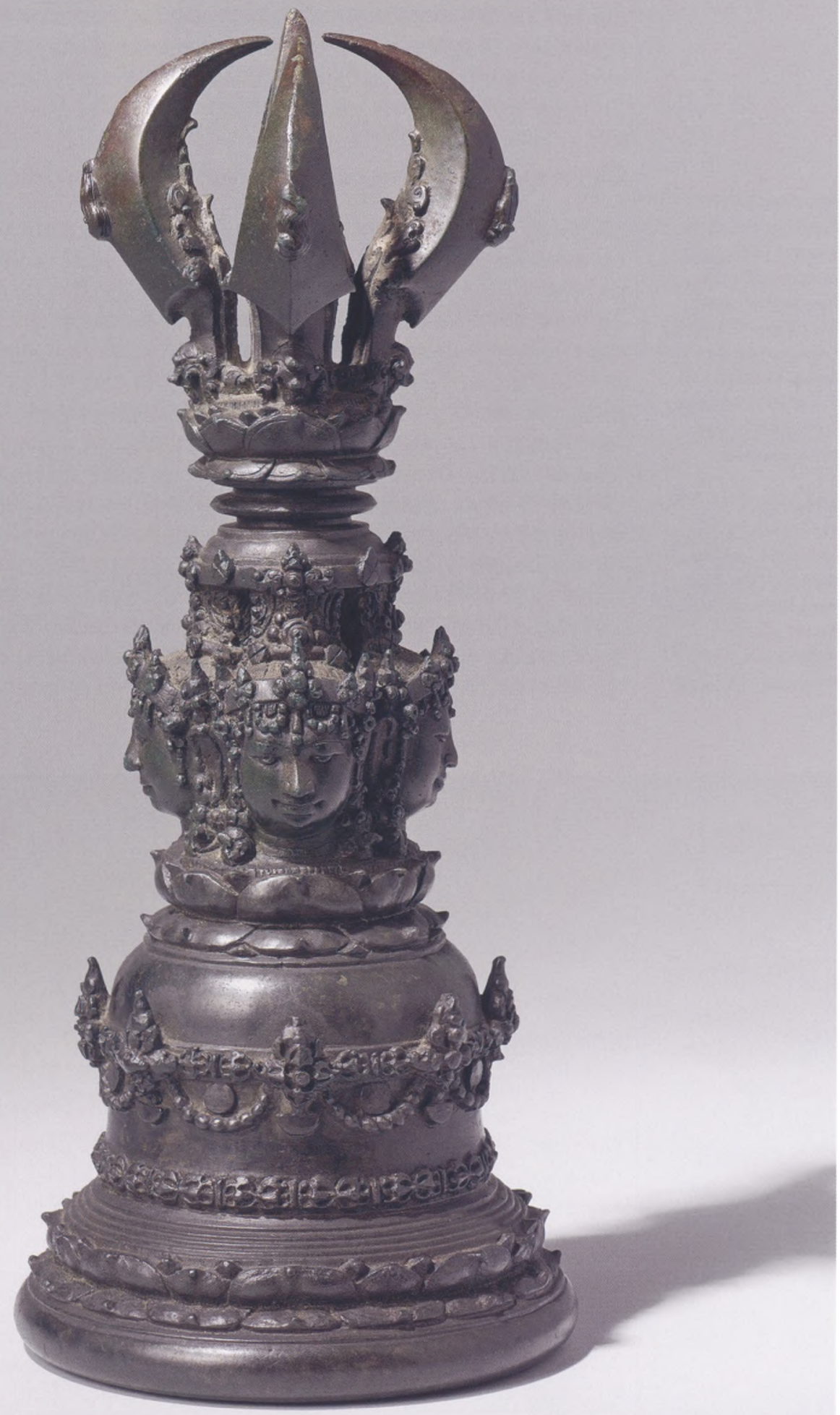


vaderland. Etnografische musea moesten volgens het manifest overigens ook blijven bestaan, maar dan alleen voor het opdoen van algemene, praktische kennis bij ambtenaren die naar de koloniën zouden gaan. ${ }^{14}$

\section{Afbeelding 8}

De bronzen priesterbel (ghanta) is bekroond door een vajra. De bel bestaat uit drie delen: de klokvormige bel, het handvat met de vier gezichten en de top in de vorm van een vajra. Priesterbel, brons, stijl Midden-Javaans, hoogte $18,5 \mathrm{~cm}$., Java, $9^{e}$ eeuw, Rijksmuseum Amsterdam, inv.nr. MAK 314.
Hoewel deze vereniging met haar perceptie van Aziatische voorwerpen als kunst een heel andere weg insloeg dan de volkenkundige musea van dat moment, waren deze gedachten eerder het gevolg van een evolutionair als van een revolutionair denkproces. Enkele jaren daarvoor, in 1915, had het Koloniaal Instituut een tentoonstelling in het Stedelijk Museum van Amsterdam georganiseerd met als onderwerp het moderne en oude Hindoeïsme: waar in 1900 voorwerpen met een dergelijk onderwerp op de wereldtentoonstelling van Parijs nog louter als etnografica werden beschouwd, werden de Balinese beelden en schilderingen 15 jaar later als kunstnijverheid gezien. Er was dus vanaf de jaren 1910 een tendens zichtbaar die van de etnografica naar kunstnijverheid naar kunst bewoog. Deze tentoonstelling dreef grotendeels op de collecties van voormalige Indiëgangers, al dan niet geïnstitutionaliseerd bij instellingen als het Koloniaal Instituut of Artis. Ook bij de VVAK werd de vereniging voor een aanzienlijk deel gedragen door mensen die in Indië, onder invloed van de hierboven geschetste ontwikkelingen, hadden verzameld. $\mathrm{Zij}$ makten echter niet de meerderheid uit: ongeveer 40 procent van de leden van het eerste bestuur had een deel van hun leven beroepsmatig in Indië doorgebracht. De nadruk bij de meeste van hun collecties lag op oudheidkundige objecten uit Java en Sumatra, omdat de meeste Europeanen er nog steeds van overtuigd waren dat de moderne Javaan geen erfgenaam kon zijn van deze antieke, verheven cultuur en zij als vertegenwoordiger van een beschaafde natie de zorg daarvoor droegen. De bestuursleden waren mannen als de koloniale spoorwegingenieur en later ondernemer Jan Willem IJzerman (1851-1932), Indisch mijningenieur Reinier D. Verbeek (1841-1926), Hugo Loudon (1860-1941), een van de stichters van Koninklijke Olie (hij had een collectie Indo-Javaanse voorwerpen van zijn oom Alex jr. Loudon (18221868) geërfd die op zijn beurt weer was geïnspireerd door zijn oom, Frans Valck) en militair en archeoloog Theo van Erp (1874-1958). Bij de tentoonstelling van 1922 van de VVAK over 'Indische beeldhouwkunst' bestond maar liefst de helft van de inzenders uit oud-Indiëgangers. Voor de tentoonstelling van 1936 over Aziatische kunst in openbare en particuliere collecties zonden ook oud-Indiëgangers hun collecties in: zij maakten nog steeds 40 procent van de particuliere inzenders uit.

Sommige van de collectiestukken die op de tentoonstellingen van 1922 en 1936 werden gepresenteerd kenden een verzamelgeschiedenis van meer dan 130 jaar. Zo stuurde in 1922 Hugo Loudon voor het eerst in de familiegeschiedenis een deel van de collectie van zijn oom Alex Loudon jr. in (waaronder de beroemde priesterbel) (afb. 8) en Anna Resink-Wilkens, dat jaar toevallig voor verlof in Nederland, bracht een mooie, oude drie-armige bronzen Hindoe-Javaanse kandelaar (afb. 6) en verschillende talams in. Deze voorwerpen kwamen symbool te staan voor de tentoonstelling die als pleidooi moest dienen voor het bestaansrecht van Aziatische kunst als kunst en niet als etnografica: 'kan men zich rijker, maar ook nobeler ornament denken dan de tempelschel (...), de drie-armige lamp met haar ranke bloemlijnen en, of de bronzen offerschalen met hun sober, altijd weer wisselend en uiterst suggestief décor?' ${ }^{15}$ In de algemene tentoonstelling van 1936 in het Stedelijk Museum waren voorwerpen te bezichtigen uit de beroemde collecties Scheepmaker uit Surabaya en Dieduksman uit Yogyakarta. 
Afbeelding 9 In boeddhistische teksten werd Boeddha omschreven met krullen, gesloten oogleden en een lichte glimlach om zijn lippen. Dit beeld voldoet volledig aan de beschrijving. Kop van Boeddha, afkomstig van de Borobudur, stijl Midden-Javaans, andesiet, hoogte $31 \mathrm{~cm}$., Java, $8^{e}-9^{e}$ eeuw, Rijksmuseum Amsterdam, inv.nr. MAK 239.

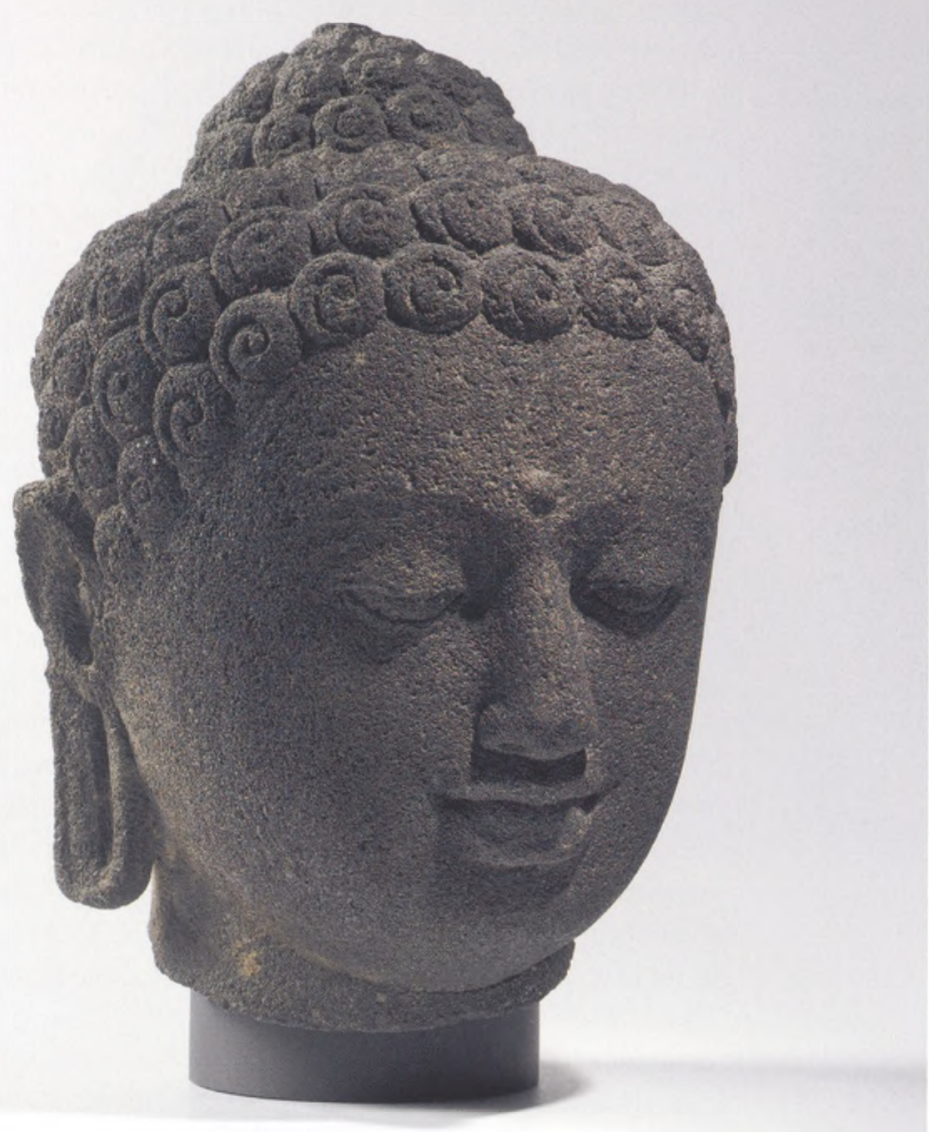

De vroeg in de $19^{c}$ eeuw verworven Boeddhahoofden van de Borobudur doken tevens op in de collecties van de VVAK. Zo verwierf in 1948 de Rotterdamse bankier Willy van der Mandele (1883-1951) van een andere verzamelaar een dergelijk 'hoofd'. Zijn vrouw, Alida van der MandeleVermeer (1861-1924), was de kleindochter van de Centraal-Javaanse tabaksplanter George Birnie (1831-1904) en diens vrouw, de Javaanse Rabina (circa 1844-1912). Alida was nog genoeg Javaanse om het hoofd, dat zijn vorige eigenaars onheil zou hebben gebracht, in 1948 onmiddellijk te schenken aan de VVAK (afb. 9). ${ }^{16}$ Ook W.G.F.C. Rissink, een voormalig hoge ambtenaar bij de Algemene Secretarie te Buitenzorg, gaf in 1933 een dergelijk hoofd in bruikleen aan de VVAK. ${ }^{17}$

Een kris van Diponegoro, buitgemaakt tijdens de Java-oorlog ruim 100 jaar eerder, werd in 1936 op een tentoonstelling van de VVAK gepresenteerd. De kris bevond zich op dat moment in de collectie van de in Indië geboren rechtbankpresident en amateurkunstenaar Jan Gerard Huijser (1878-1962). Op diezelfde tentoonstelling van de VVAK kon men een pusaka-beeld, Ciwa als Batara Guru, van Diponegoro aanschouwen. Het beeld, op dat moment in handen van alles-verzamelaar Jhr C.H.C.A. Sypestein (1857-1937), was verworven van een andere jonkheer die het van de eerste verzamelaar, oud access $^{2}$ 


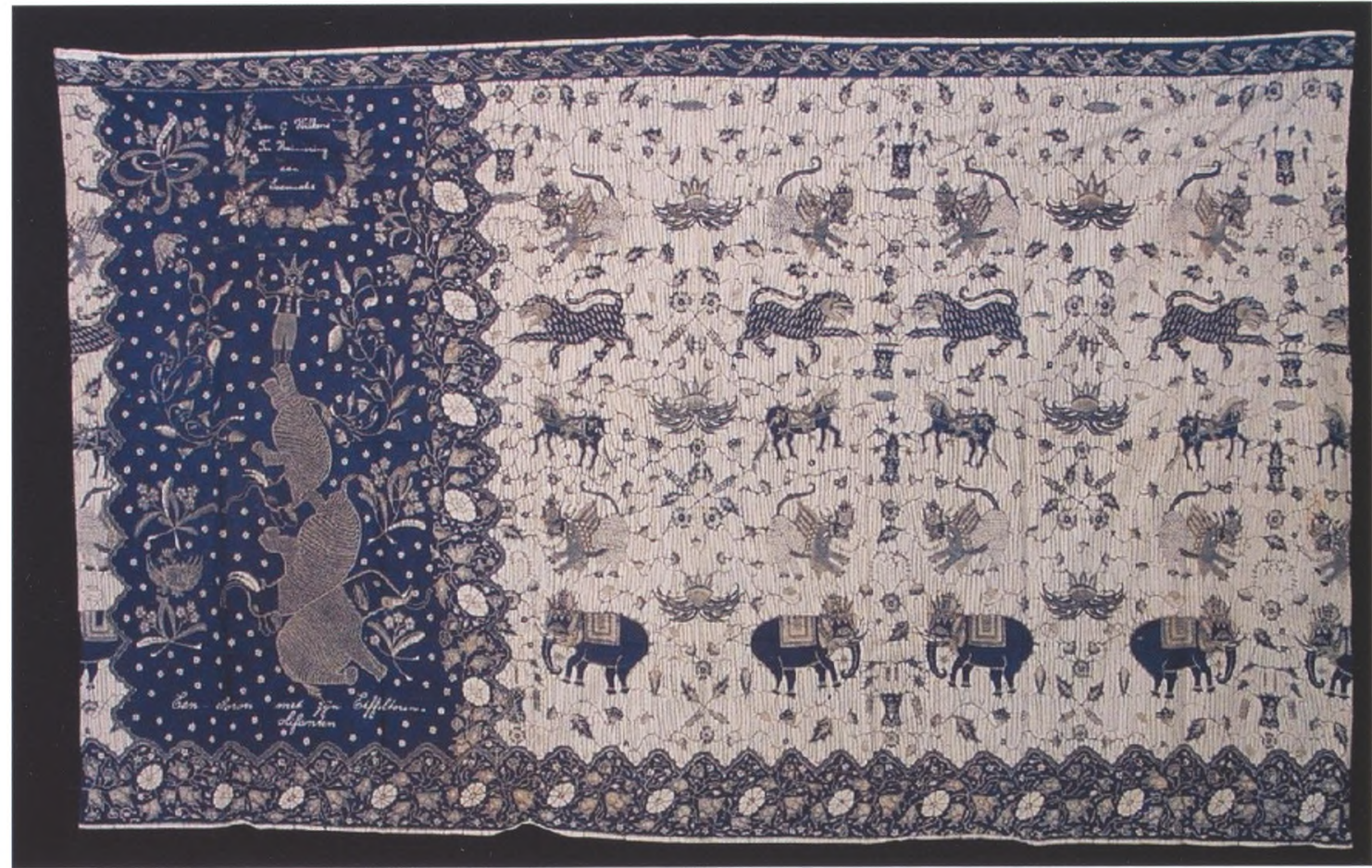

Afbeelding 10 Batiks werden cadeau gegeven aan dierbaren. Hier een batik die decennialang in de familie van Anna Resink-Wilkens op Java bewaard is gebleven en in de $20^{\circ}$ eeuw geschonken is aan het Tropenmuseum, Amsterdam. Op de batik is geschreven 'aan C. Wilkens ter herinnering aan Soemiati'. Batik, Java, ca. 1850 , Tropenmuseum, inv.nr. 2097-17. infanterie-officier tijdens de Java-oorlog, Carel P.A. baron de Salis Soglio Mayenfeld (1800-1871) had verkregen. Behalve dat dit beeld en deze kris van Diponegoro als voorwerpen van de beroemde Javaanse prins werden gepresenteerd, waren ze in Amsterdam ook en vooral kunst. Het is echter de vraag of dit specifieke beeld of die kris in de tentoonstelling waren geplaatst als er niet deze verzamelgeschiedenis achter zat. Zo was wat er op de eerste tentoonstellingen van 1922 en 1936 (de tentoonstelling van 1919 betrof Oost-Aziatische kunst en kende logischerwijs weinig oud-Indiëgangers) gepresenteerd werd als beeldhouwkunst voornamelijk Javaans, afkomstig uit de boeddhistische en hindoeïstische koninkrijken, of modern en oud hindoeïstisch Balinees. Topeng-maskers uit Java werden in 1936 ook als kunst opgevat. Daarnaast werden antieke gouden en zilveren voorwerpen en weefsels en batiks ('textielkunst') uit Java, Bali en Sumatra onder kunst gerekend (afb. 10). Niet alleen is dit grotendeels een afspiegeling van wat Raffles meer dan 100 jaar eerder reeds verzamelde, maar ook waren de voorwerpen vooral verzameld onder invloed van maatschappelijke invloeden van decennia of soms zelfs een eeuw eerder. 'Nieuwe' kunstuitingen, zoals moderne en antieke Balinese schilderijen, werden niet als kunst gepresenteerd.

\section{Tot slot}

Van statussymbolen, trofeeën, relatiegeschenken, souvenirs en referentiecollecties voor het onderwijs van de lokale bevolking transformeerden de voorwerpen bij de VVAK tot autonome kunst waarin de koloniale context 
verdween. Die context moet men echter niet uit het oog verliezen: er is wel degelijk sprake van invloed van koloniale verzamelaars uit Nederlands-Indië op de stichting en ontwikkeling van de vereniging. Ook de Westerse opvatting van Indonesische kunst rond 1920 is hierdoor beïnvloed. Kortom, het verzamelen in Indië, gedragen door de koloniale Europese elite en beïnvloed door maatschappelijke ontwikkelingen als oorlogen, de opkomst van het historisch besef, opvattingen over cultuur, de mate van direct bestuur in de kolonie en politiek beleid, hadden invloed op de definitie van wat men rond 1920 onder Aziatische kunst ging verstaan en werkt nog steeds, in ietwat veranderde vorm, door in onze percepties van kunst uit Indonesië.

Caroline Drieënhuizen is afgestudeerd in geschiedenis en behaalde minors in kunstgeschiedenis en algemene cultuurwetenschappen. Haar speciale aandacht geldt koloniale gemeenschappen, verzamelen en etnografische objecten. $\mathrm{Zij}$ is verbonden aan de Open Universiteit Nederland en aan de Universiteit van Amsterdam waar zij momenteel werkt aan de afronding van haar proefschrift.

\section{Literatuur}

Erp, T. van, 'Nieuwe aanwinst in bruikleen van een Boeddhakop van den Baraboedoer', Bulletin van de Vereeniging van Vrienden der Aziatische Kunst 10/1 (1933), pp. 253-256.

Fontein, J., 'De vroege jaren van de Vereniging', Aziatische Kunst 35/2 (2005), pp. 6-8. Hoijtink, M., Caspar J.C. Reuvens en de musea van oudheden in Europa (1800-1840), Amsterdam, 2009 [onuitgegeven proefschrift. Handelsuitgave in voorbereiding]. 'Indische beeldhouwkunst', Het Vaderland, 22 september 1922.

Lunsingh Scheurleer, P., 'Collecting Javanese antiquities. The appropriation of a newly discovered Hindu-Buddhist civilization', in: Pieter ter Keurs (red.), Colonial collections revisited, Leiden, 2007, pp. 71-114.

Miedema, R., 'Kop van een boeddhabeeld', Aziatische Kunst 38/3 (2008), pp. 29-30.

Pomian, K., 'The collection: between the visible and the invisible', in: S. Pearce (red.), Interpreting objects and collections, Londen, 1994, pp. 160-174.

Rapporten van de Commissie in Nederlandsch-Indië voor Oudheidkundig Onderzoek op Java en Madoera (1905-1906).

Steenbergen, R., 'De Vereniging van Vrienden der Aziatische Kunst in het interbellum: deftige verzamelaars, rijke donateurs en Indische fortuinen', Aziatische Kunst 38/3 (2008) pp. 3-16.

Stutterheim, W.F., 'De oudheden-collectie Resink-Wilkens te Jogyakarta', Djawa 14 (1934), pp. 167-197.

Valck, F. G., 'Gedachten over de ruinen van de Hindoesche Godsdienst, welke op Java gevonden worden', Tijdschrift voor Nederlandsch Indië 3 (1840), pp. 177-203.

\section{Archieven}

Koninklijk Instituut voor Taal-, Land- en Volkenkunde (KITLV), Leiden.

Archief Henri Titus Damsté, H 1084. Inv.nr. 71. Brief Henri T. Damsté aan familie, d.d. aan boord van de SS 'Van den Bosch', van Surabaya naar Makasar, 26 januari 1904. Noord-Hollands Archief, Haarlem.

476. Archief van het Rijksmuseum en rechtsvoorgangers te Amsterdam, 1807-1945. Inv.nr. 2506. Doorslag van een rapport van H.F.E. Visser inzake de wens tot stichting van een Rijksmuseum voor Aziatische kunst in het kader van de reorganisatie van de Nederlandse musea (ca. 1920). 
1. R. Steenbergen, 2008, pp. 4-5.

2. Verzamelen moet hier dan ook niet opgevat worden in zijn kunsthistorische definitie waarin men uitgaat van systematiek, classificaties en de drang tot het complementeren van de collectie: in navolging van filosoof en historicus Krzysztof Pomian licht ik de activiteit uit zijn kunsthistorische betekenis en definitie en zie ik het als het actief vergaren van objecten met bijzondere redenen om die tijdelijk of voorgoed uit het economische circuit te ontrekken en te onderwerpen aan bijzondere bescherming [K. Pomian, 1994, p. 162]. Kortom, ik [CD] beschouw verzamelen als een activiteit au fond.

3. T. van Erp, 1933, pp. 253-256.

4. M. Hoijtink, 2009 (onuitgegeven proefschrift).

5. W.F. Stutterheim, 1934, pp. 167-197.

6. Rapporten van de Commissie in Nederlandsch-Indië voor Oudheidkundig Onderzoek op Java en Madoera (1905-1906).

7. Rapporten van de Commissie, Op.cit, p. 56.

8. P. Lunsingh Scheurleer, 2007, p. 76.

9. Frans G. Valck, 1840, pp. 177-203.

10. Hoijtink, Op. cit.

11. Een van verzamelaars in Nederland met een Nederlands-Indische afkomst die voorwerpen uit de collectie Dieduksman verwierf, was de kleinzoon van de oudgeneraal uit de Java-oorlog met dezelfde naam Frans D. Cochius (1869-1920). De musea die objecten uit deze collectie verworven hadden, waren het 's Rijks Ethnographisch Museum in Leiden, het Museum voor Land- en Volkenkunde in Rotterdam en volkenkundige musea in Berlijn, Dresden en Essen (het Folkwang Museum).

12. Frans Valck ontving rond 1835 Indo-Javaanse voorwerpen van landhuurder Johannes A. Dezentjé (1797-1839). Dezentjé had ze op zijn land gevonden. Bastiaan van Baak, de resident van Yogyakarta tussen 1877 en 1889, ontving als cadeau van planter Karel A.E. Kläring (1845-1906) een gouden Hindoe-Javaans beeld. Karels vader was Andreas E. Kläring (1802-1875) geweest: die had land gehuurd tussen de Javaanse tempels Candi Sewu en het Prambanan-complex. Mede daardoor had Kläring een grote collectie Hindoe-Javaanse voorwerpen en beelden bijeen kunnen verzamelen. De kinderen van Kläring sr., waaronder Karel en zijn zus Johanna, erfden de collectie die aan het eind van de $19^{e}$ eeuw voor een deel aangekocht werd door het Museum van het Bataviaasch Genootschap.

13. KITLV, H 1084. Inv.nr. 71.

14. Noord-Hollands Archief, 476.

15. Het Vaderland, 1922.

16. Jan Fontein, 2005, pp. 6-8 en Rapti Miedema, 2008, pp. 29-30.

17. Van Erp, Op. cit. 